\title{
Climate change research and policy in Portugal
}

\author{
Anabela Carvalho, ${ }^{1, *}$ Luísa Schmidt, ${ }^{2}$ Filipe Duarte Santos ${ }^{3}$ and \\ Ana Delicado 2
}

This article offers a review of research and policy on climate change in Portugal and is organized into three main themes: scientific knowledge and assessment of climate change; policy analysis and evaluation; and public engagement. Modern scientific research on meteorology and climatology started in Portugal in the 1950s and a strong community of researchers in climate science, vulnerabilities, impacts, and adaptation has since developed, particularly in the last decade. Nevertheless, there are still many gaps in research, especially regarding the economic costs of climate change in Portugal and costs and benefits of adaptation. Governmental policies with a strong emphasis on mitigation were introduced at the end of the 1990s. As greenhouse gas emissions continued to rise beyond its Kyoto target for 2012, the country had to resort to the Kyoto Flexibility Mechanisms in order to comply. Climate change adaptation policies were introduced in 2010 but are far from being fully implemented. Regarding public engagement with climate change, high levels of concern contrast with limited understanding and rather weak behavioral dispositions to address climate change. Citizens display a heavy reliance on the media as sources of information, which are dominated by a techno-managerial discourse mainly focused on the global level. The final part of the article identifies research gaps and outlines a research agenda. Connections between policy and research are also discussed. ๑ 2013 John Wiley \& Sons, Ltd.

How to cite this article:

WIREs Clim Change 2014, 5:199-217. doi: 10.1002/wcc. 258

\section{INTRODUCTION}

A discussion of the origins and development of climate change science, policies, and public understanding in Portugal is presented in this tripartite article. We start by reviewing research on climate change and impacts, adaptation, and mitigation and then move to an analysis of public policies and related research. The third part focuses on public understanding and engagement, as well as on media discourses.

\footnotetext{
*Correspondence to: carvalho@ics.uminho.pt

${ }^{1}$ Department of Communication Sciences, University of Minho, Braga, Portugal

${ }^{2}$ Institute of Social Sciences, University of Lisbon, Lisbon, Portugal

${ }^{3}$ Faculty of Sciences, University of Lisbon, Lisbon, Portugal

Conflict of interest: The authors have declared no conflicts of interest for this article.
}

The ways climate change is viewed and addressed in a given country depend on its cultural, political, and scientific backgrounds and also, to a large extent, on the specific aspects of the changing climate in that country and on its actual and perceived future impacts. Under a dictatorial regime for nearly half a century, Portugal reached the 1970s with low levels of education, a weak industrialization and poor economic records. The 1974 revolution started a process of intense political, social and economic change, the latter being particularly pronounced after the country became a member of the European Union (EU) in 1986, 2 years before the establishment of the IPCC. With little tradition of environmental politics and values, all of Portugal's governmental climate change policies have been shaped and applied under the strong influence of the EU. At the end of the 1980s the debate on climate change reached the EU's official agenda. In 1990, the European Commission proposed to the Council a strategy to stabilize greenhouse 
gas (GHG) emissions by using a mix of efficiency standards and fiscal instruments, and also to promote research. At that time adaptation was marginalized as a public policy issue because of an optimistic view that mitigation would be much more effective than it actually turned out to be at the global level. Presently, the EU fully recognizes the need to adapt to climate change and the Commission adopted a strategy on adaptation in April 2013.

In the 1990s, there was very little knowledge about the nature, intensity, and distribution of climate change impacts across Europe. These questions were addressed mainly at the national level by the scientific community of each country. Portugal was the first southern European country to develop and publish an integrated assessment on climate change vulnerabilities, impacts, and adaptation in 2002. ${ }^{1}$ That study concluded that due to its situation at the extreme southwestern part of Europe, Portugal is particularly vulnerable to climate change impacts that result mainly from a decreasing annual precipitation, more intense extreme weather and climate events, particularly heat waves, droughts, and inundations associated with heavy precipitation events, and mean sea level rise. Being a small country with low levels of industrialization, Portugal makes a relatively small contribution to global GHG emissions. In 2008, Portugal emitted 56.31 million $\mathrm{tCO}_{2}$, which represented $0.18 \%$ of world emissions. ${ }^{2}$

Portugal's political and institutional framework on climate change was developed in the 1990s further to the ratification of the United Nations Framework Convention on Climate Change (UNFCCC) in 1992 and, especially, the signing of the Kyoto Protocol in 1998 (ratified in 2002). While most EU member countries pledged to start reducing their GHG emissions immediately after the Kyoto Protocol, Portugal and a few other EU member countries (Greece, Ireland, Spain, and Sweden) were allowed to increase their emissions until 2012 under the Burden Sharing Agreements, which was intended to compensate for the different national levels of emissions per capita in the EU. ${ }^{3}$ Due to its low level of emissions at the time, Portugal was allowed to increase them by $27 \%$ from the baseline year of 1990 until $2012 ;{ }^{4}$ still, it had difficulty fulfilling this commitment. In this article, we review research on Portugal's climate policies that may help understand the country's track record in mitigation and adaptation to climate change.

The Portuguese society had a late awakening to environmental issues. It was only in the 1980 s, after decades of dictatorial rule, that an environmental conscience started to emerge. ${ }^{5}$ A recent analysis of 30 years of Eurobarometers shows that levels of interest of the Portuguese for the environment have raised since the mid-1980s but also that there have been multiple contradictions in people's attitudes. ${ }^{6}$ The first extensive study of public perceptions on the environment, conducted in $1997,{ }^{7}$ evidenced a contrast between high levels of concern ${ }^{8}$ and an ecocentric tendency, ${ }^{9}$ on the one hand, and low levels of knowledge $\mathrm{e}^{10}$ and low levels of pro-environment behavior, ${ }^{11}$ on the other hand. In this article, we discuss the studies that have analyzed public understanding of and behavior toward climate change. We also look at the sources of information that people use and analyze the findings of research on media representations of climate change.

\section{SCIENCE AND ASSESSMENT OF CLIMATE CHANGE}

\section{A Brief History of Climate Research}

The oldest Portuguese weather station to provide a continuous record of meteorological data was established in Lisbon in 1854 by Infante D. Luís, brother to King D. Pedro V. Portugal was one of the founding members of the International Meteorological Organization created in 1878. Regular meteorological observations were performed since the middle of the 19th century in various localities in continental Portugal, Azores, Madeira, and also in its colonies in Africa and Asia. In 1946, the National Meteorological Weather Service was established simultaneously with the creation of the first university course in geophysical sciences at the University of Lisbon. These initiatives marked the starting point for the development of meteorology and climatology research in Portugal. José Pinto Peixoto (1922-1996), a leading professor in that course, later became one of the most internationally well-known Portuguese climatologists. Peixoto developed a close scientific collaboration with Victor Starr and Edward Lorenz of MIT, Barry Saltzman of Yale and Abraham H. Oort of Princeton, mainly in the field of the general circulation of the atmosphere and the global water cycle. In 1992, he published the book Physics of climate, ${ }^{12}$ in collaboration with Oort, which is still a valued reference text in climatology. The book addresses briefly the problem of climate change induced by anthropogenic carbon dioxide emissions. It refers to Hansen's papers ${ }^{13,14}$ and to the 1979 and 1982 reports of the US National Academy of Sciences on the $\mathrm{CO}_{2}$, question ${ }^{15,16}$ and gives a strong emphasis to the uncertainties involved in the models used to create future climate scenarios. At the time most atmospheric scientists felt that any statement about climate change 
was premature and engaging in a dialog with policymakers and the public on these matters was time away from doing science. Peixoto did not engage in climate change research and he did not encourage the researchers trained by him at the University of Lisbon to do so.

The first paper ${ }^{17}$ that addressed climate change and its impacts in Portugal was published in 1987 in Portugaliae Physica. ${ }^{\text {a }}$ A model integrating the perturbed carbon cycle and the atmosphere and biosphere responses to a changing climate was developed. It projected that $\mathrm{CO}_{2}$ concentration would double relative to pre-industrial values by 2080 leading to an increase in the lower atmosphere global average temperature of $2.5^{\circ} \mathrm{C}$. The assessment of the impacts of this climate change scenario for Portugal indicated potentially negative effects in the biosphere and in particular an increase in the risk of desertification, especially in the southern part of the country. In the second half of the 1990s, Portuguese researchers started to consider the problem of downscaling of General Circulation Model (GCM) climate scenarios for Portugal and to assess the reliability of different methodologies. ${ }^{18-21}$ Major advances in projecting future climate scenarios for Portugal have been made since the beginning of this century. Special attention has been paid to the study of extreme weather and climate events, particularly as regards temperature ${ }^{22}$ and precipitation, ${ }^{23,24}$ because they are very likely to cause the most adverse impacts.

\section{Observed Climate Trends}

Portugal has a Mediterranean type of climate characterized by warm and dry summers and cool and wet winters. The mean annual air temperature varies between $7^{\circ} \mathrm{C}$ in the inner highlands of central Portugal and $18^{\circ} \mathrm{C}$ in the southern coast. The mean annual precipitation is around $900 \mathrm{~mm}$ with a strong north-south gradient, reaching values of $3000 \mathrm{~mm}$ in the northwest mountains and values below $500 \mathrm{~mm}$ in the southeastern part of the country.

Studies of global temperature evolution since the beginning of the last century have indicated two periods of warming, 1910-1945 and 1976-2000, separated by a period of cooling, 1946-1975. This behavior is also apparent in the time series of mean temperature in Portugal ${ }^{1}$. In the period 1976-2006, the annual mean temperature in the country increased by $0.52{ }^{\circ} \mathrm{C}$ per decade 22 , which is more than double the rate of mean annual global temperature increase. Eight of the ten warmest years occurred in the last 20 years, with 1997 being the warmest since 1941. Heat waves have occurred in the years 1981, 1991, 2003, 2006, 2009, and 2010, becoming more frequent since the beginning of this century. In the Portuguese archipelagos of Azores and Madeira there is also a clear trend of increasing annual mean temperature. Camuffo et al. ${ }^{25}$ have reconstructed the evolution of temperature and precipitation series from instrumental observations in the Western Mediterranean, including Portugal, since 1654 and identified periods of correlation and anti-correlation up to the present.

Precipitation in Portugal shows high interannual variability. Most of the annual precipitation is accumulated through migratory storms during the period of November to April. On average, 42\% of the annual precipitation falls in winter, from December to February, and only $7 \%$ in summer, from June to August. In the spring and autumn transition seasons the amount of precipitation is highly variable. Recent studies ${ }^{26}$ have shown that in the Mediterranean climate region, from the Atlantic coasts of Portugal and Morocco to the Middle East, precipitation in the cold season from November to April has been decreasing significantly since 1970 . In the period 1902-2010, the region has experienced 10 of the 12 driest winter seasons in the last 20 years. Studies specifically for Portugal are in agreement with this regional trend. Costa and Soares ${ }^{27}$ reported an increase in the length of dry spells and a tendency toward drier climatic conditions for the period 1955-1999 in southern Portugal. The last 30 years have been particularly dry in mainland Portugal with severe droughts in 2004-2005 and 2011-2012.The year of 2005 was the driest in the last 78 years, followed by 2007 and 2004. Another probably significant trend in the current century is the occurrence of extremely wet winters such as in $2010^{23}$ and 2013. All these observations are consistent with a tendency of more intense and frequent extreme weather and climate events, in particular heat waves, droughts and annual number of very wet days. The observed trends are very similar to those projected by the future climate scenarios as regards both temperature and precipitation. In fact the Mediterranean region, including mainland Portugal, is a climate change hotspot. ${ }^{28}$ By the latter decades of the 21st century, the Mediterranean is expected to experience the greatest drying among 26 regions across the globe.

\section{Assessments of Climate Change}

The assessment of vulnerability, impacts and adaptation to climate change in Portugal using GCM scenarios was initiated in 1999 with the project 
SIAM-Climate Change in Portugal: Scenarios, Impacts, and Adaptation Measures. ${ }^{1}$ The SIAM I final report involved an analysis of the 20th century climate, climate scenarios and socioeconomic scenarios for continental Portugal, and an integrated and multisectorial assessment of the impacts of climate change, including water resources, coastal zones, agriculture, human health, energy, forests, biodiversity, and fisheries. This assessment report was the first for a Southern European country. Contrary to what happened in most countries, this project was promoted by a group of concerned scientists and funded by research funding agencies on a competitive basis, not the Portuguese Government Programme on climate change.

The SIAM team continued the assessment work in 2002, this time funded by a grant from the Portuguese Environmental Programme (supported in large part by the EU European Regional Development Fund). The SIAM II final report ${ }^{29}$ updated the analysis of the 20th century climate and future climate scenarios for Portugal, including Azores and Madeira, as well as the previous integrated and multisectorial assessment for continental Portugal. Furthermore, it reported on a pioneering process of outreach and consultation on the impacts and adaptation measures to climate change with stakeholders of different socioeconomic sectors. SIAM originated a considerable number of research papers on vulnerability, impacts, and adaptation (VIA) to climate change in Portugal in various sectors, such as water resources, ${ }^{30}$ coastal zones, ${ }^{31}$ health, ${ }^{32,33}$ forests, biodiversity and fisheries. ${ }^{34}$ It was also a first step in the process of dissemination of information to central and local administrations, to policy-makers and to the general public on the risks and opportunities of climate change in Portugal in different socioeconomic sectors and biophysical systems.

The findings of SIAM indicate clearly that the increasing average temperature, the more frequent heat waves (Figure 1) and the very likely decrease in precipitation and intensification of droughts will have significant adverse effects in various socioeconomic sectors, such as water resources, ${ }^{35,36}$ agriculture, forests, biodiversity, health, and tourism. This will amplify the vulnerability to desertification that already affects $36 \%$ of the continental territory. Another major concern is the increase in the risk of inundation and land loss in the Portuguese continental coast (where erosion is already significant in about $67 \%$ of its length) due to sea level rise. ${ }^{37,38}$

Climate change VIA research on health in Portugal was also initiated with SIAM $^{32,33}$ and emphasized especially heat-related mortality, air pollution-related health effects, and vector-borne diseases. The results of this research were used to establish the Health Ministry's National Contingency Plan for Heat Waves after the dramatic impact of the 2003 heat wave on mortality in the country. An operative national heat wave early warning system was implemented to reduce the adverse effects of future heat wave episodes. Later research on the impacts of climate change on human health has focused mainly on heat waves ${ }^{39}$ and air pollution. ${ }^{40,41}$

SIAM also produced research on the impacts of future wave climate scenarios on erosion in the drift-aligned Portuguese west coast. ${ }^{42}$ The HadCM3 model wind field scenarios for 2060-2099 were used to force the ocean waves. Results indicate a future clockwise rotation in the wave direction with an estimated magnitude between $5^{\circ}$ and $7^{\circ}$ that increases the longshore drift of sediments by $5 \%-15 \%$. The increased drift will very probably exacerbate the chronic erosion problems that exist in that coast.

An assessment similar to the SIAM project was developed for the Madeira Islands with the project CLIMAAT II, ${ }^{43}$ funded by the Regional Government of Madeira and the INTERREG III B EU Programme. Impacts and adaptation measures to climate change for water resources, forests, agriculture, biodiversity, health, tourism, and energy were assessed until 2100 based on GCM scenarios. ${ }^{44}$ One of the major outcomes of CLIMAAT II was to alert to the increase in the risk of dengue fever in the island of Madeira since the competent vector was introduced in 2004 in the capital, Funchal, and the warming climate was becoming more favorable for its development. Recommendations were made to monitor and control the population of Aedes aegypti in Madeira. Nevertheless, dengue appeared in October 2012 and the number of infected persons reached more than 1800 within less than 2 months.

After the assessment of climate change vulnerabilities and impacts at the national level and the regional assessment for the Madeira archipelago, the next natural step would be to initiate assessment studies of climate change vulnerabilities and impacts at municipal level in order to construct and implement local adaptation strategies. Very few municipalities have undertaken this kind of study and in all the cases it has been done without direct support from the government. Integrated and multisectorial climate change adaptation and mitigation strategies were developed for the towns of Sintra, Cascais, and Almada (all in the greater Lisbon area). The strategic plan for adaptation and mitigation of climate change in the Sintra municipality ${ }^{45}$ was developed in 2008-2009 and includes the study of impacts and adaptation measures in specific sectors. Mitigation 


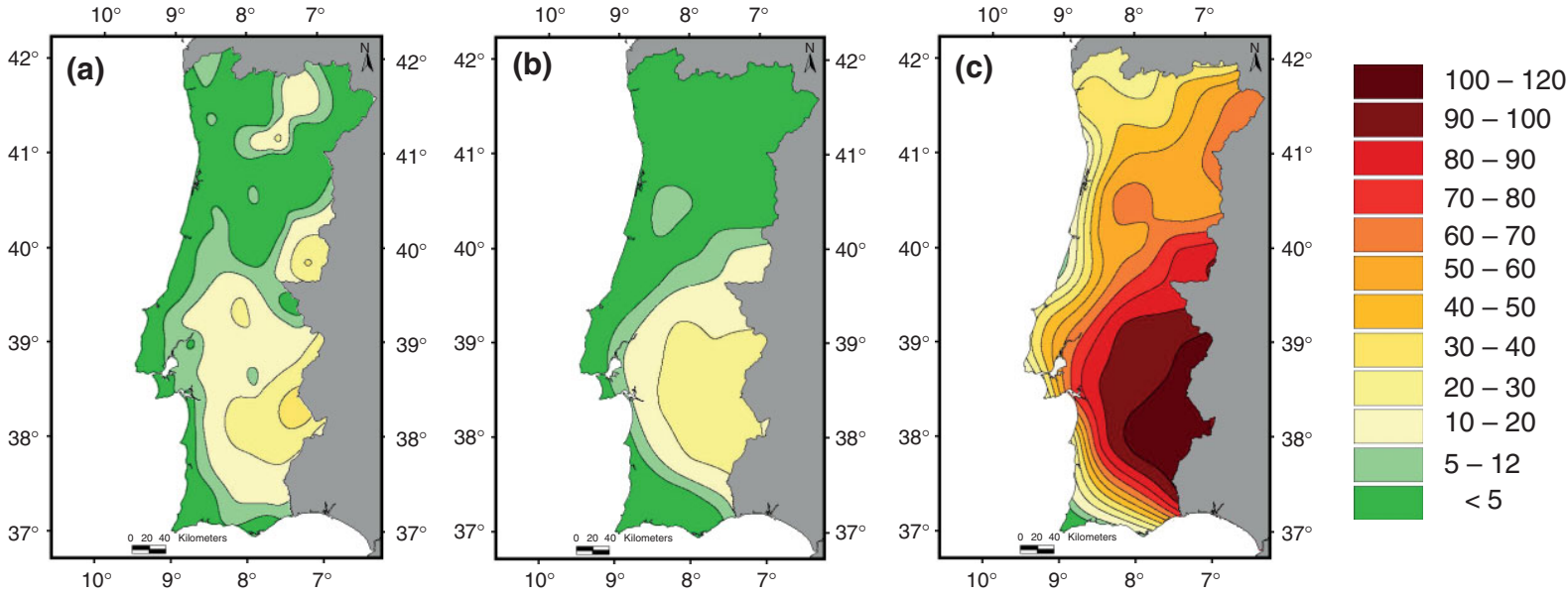

FIG URE 1 | Number of hot days per year with maximum temperature above 35 (summer days) for the (a) 1961-1990 climatology; (b) HadRM2 control simulation; (c) IS92a HadRM2 simulation (2081-2100). Source: Ref 28, Figure 2.66, p. 90.

strategies were proposed, based on downscaled socioeconomic scenarios projected for Portugal up to $2070 .{ }^{46}$ A similar plan was developed for the Cascais municipality in 2009-2010. ${ }^{47}$ However, at the national level, the multisectorial and integrated approach was discontinued after SIAM II in 2006.

Climate change impacts on biodiversity in the Iberian Peninsula have been addressed in the Iberia Change project, ${ }^{48}$ a joint initiative of the Portuguese and Spanish Governments. The Iberian Peninsula is a biodiversity hotspot that is particularly vulnerable to climate change. ${ }^{49,50}$ Biodiversity in Portugal has been negatively affected by the increasing number of forest fires in recent decades. A study on the impact of climate change on fire activity in 12 districts across Portugal projects that fire occurrence and burned area will increase dramatically in the future ${ }^{51}$ if adequate adaptation measures are not implemented. As regards marine biodiversity the impact of sea-surface warming on fish assemblages of the Portuguese continental coast under various climate scenarios indicates an increase in the number of species, suggesting that a commercial opportunity for fisheries may arise. ${ }^{52}$

The impacts of climate change on tourism in Portugal have been studied by the CLITOP project, ${ }^{53}$ which focused mainly on future scenarios of outdoor thermal comfort in four Portuguese tourism regions (Lisbon, Oporto, Faro, and Madeira), concluding that the annual distribution of tourism fluxes from different country origins to Portugal are likely to change in the future.

Research on the heat island effect in Lisbon has suggested that it tends to be aggravated in scenarios of climate change and that urban planning policies should be designed in accordance. ${ }^{54,55}$
Three large research projects on a climate change strategy for the Lisbon water supplier (EPAL), ${ }^{56}$ on climate change impacts in coastal areas ${ }^{57}$ and on inundation risk in Portugal under climate change (for the Portuguese Association of Insurers $)^{58}$ were at the finishing stages at the time of writing.

Research into climate change mitigation in Portugal has been mainly focused on the use of optimisation models for reducing $\mathrm{CO}_{2}$ emissions under various energy policy scenarios. The TIMES_PT model generated with the TIMES model, developed by the International Energy Agency, has been used to derive total and marginal abatement costs for a set of energy policy scenarios for Portugal. ${ }^{59}$ The optimized scenarios have been used to construct the National Low Carbon Roadmap 2050 published in 2012 that establishes a target of $50 \%-60 \%$ reduction in GHG emissions.

\section{CLIMATE CHANGE POLICY: DEVELOPMENT AND EVALUATION}

Research on Portugal's climate change politics and policies is very sparse. This section offers a critical appraisal of the development of climate policies in the country and reviews the few existing studies.

\section{Mitigation Policies}

Dessai and Michaelowa's ${ }^{60}$ analysis of Portuguese climate change policies in the 1990s showed that Portugal was en route to failing to comply with its Kyoto target due to an increase in GHG emissions and a poor energy efficiency record. They attributed this to a weak environmental conscience of the population, 
the lack of institutional integration of policies, and the absence of a real climate policy.

Created in 1998 and composed by officials from various ministries (but no civil society representatives), the Inter-ministerial Commission on Climate Change (CAC - see Table 1 for this and other acronyms) was responsible for drafting the national strategy for climate change and for monitoring policy, at the national and international levels, for leading the decisionmaking process, and for implementing policies by introducing climate change concerns into sectorial policies. However, CAC was ineffectual and only rose in importance in the second half of the 2000s, particularly in terms of programmatic plans, strategies, and legislation aimed at fulfilling the Kyoto Protocol commitments. This marked the beginning of a period when climate change became one of the most significant environmental policy issues in Portugal. ${ }^{69,70}$

The National Strategy for Climate Change was approved in 2001 and included three main instruments: the National Programme for Climate Change, the National Plan for Allocation of Emissions Allowances, and the Portuguese Carbon Fund. Yet, it was only in the middle of the decade that public policies for mitigation of climate change started to gain relevance. A second version of the National Programme for Climate Change (PNAC) was approved in 2004, comprising measures for various sectors, such as electricity generation (with a target of $39 \%$ from renewable sources by 2010), biofuels, energy efficiency in buildings, public transport, driving, and agriculture and forestry. To ensure the monitoring and evaluation of GHG emissions and of PNAC's measures, the PNAC Assessment and Monitoring Programme, and the National Inventory of Greenhouse Gas Emissions and Sinks were approved in 2005. This resulted more from EU pressure than from endogenous change. PNAC 2004 did not have a significant practical effect and emissions continued to rise well beyond the national Kyoto target (Figure 2).

Faced with the need to design a new set of policies and measures, the government drafted a new Climate Change National Programme-PNAC 2006. According to Torres and Pinho, ${ }^{72}$ the entry into force of the EU's Emissions Trading System (ETS) in 2005 was a milestone for Portuguese climate politics as the threat of having to pay for emissions drove the government to action. PNAC 2006 expanded some policy measures and added new ones, such as an increase in wind power and an increase in thermal efficiency of new buildings, as well as the application of a carbon tax to inefficient light bulbs and the growing incorporation of the cost of $\mathrm{CO}_{2}$ emissions into car taxes. Except for the wind power sector, PNAC 2006 did not produce the desired effects concerning the reduction of GHG emissions,

TABLE 1 Policy Measures and Institutions: Acronyms, Dates, and Functions

\begin{tabular}{|c|c|c|c|}
\hline Acronym & Name & Start Date & Function \\
\hline CAC & $\begin{array}{l}\text { Inter-ministerial Commission on Climate } \\
\text { Change }\end{array}$ & 1998 & $\begin{array}{l}\text { Drafting and implementing national public } \\
\text { policy on climate change }\end{array}$ \\
\hline CECAC & $\begin{array}{l}\text { Executive Committee for the Climate Change } \\
\text { Commission }\end{array}$ & 2006 & $\begin{array}{l}\text { Coordination of public policy on climate } \\
\text { change }\end{array}$ \\
\hline PNAC 2001 & $\begin{array}{l}\text { National Programme for Climate Change } \\
2001^{61}\end{array}$ & 2001 & Set of measures for mitigating climate change \\
\hline PNAC 2004 & $\begin{array}{l}\text { National Programme for Climate Change } \\
2004^{62}\end{array}$ & 2004 & Set of measures for mitigating climate change \\
\hline PNAC 2006 & $\begin{array}{l}\text { National Programme for Climate Change } \\
2006^{63}\end{array}$ & 2006 & Set of measures for mitigating climate change \\
\hline PNAC 2020 & $\begin{array}{l}\text { National Programme for Climate Change } \\
2020^{64}\end{array}$ & 2013 & $\begin{array}{l}\text { Set of measures for mitigating climate change } \\
\text { between } 2013 \text { and } 2020\end{array}$ \\
\hline PNALE I & $\begin{array}{l}\text { National Plan for the Allocation of Emissions } \\
\text { Allowances }\end{array}$ & 2005 & $\begin{array}{l}\text { Set of measures regarding emissions trading } \\
(2005-2007)\end{array}$ \\
\hline PNALE II & $\begin{array}{l}\text { National Plan for the Allocation of Emissions } \\
\text { Allowances }^{66}\end{array}$ & 2008 & $\begin{array}{l}\text { Set of measures regarding emissions trading } \\
(2008-2012)\end{array}$ \\
\hline FPC & Portuguese Carbon Fund & 2006 & Financial instrument for carbon investment \\
\hline ENAAC & $\begin{array}{l}\text { National Strategy for Adaptation to Climate } \\
\text { Change }^{67}\end{array}$ & 2010 & $\begin{array}{l}\text { Set of measures for adaptation to climate } \\
\text { change (2010) }\end{array}$ \\
\hline RNBC & National Low Carbon Roadmap $2050^{68}$ & 2012 & Set of measures for reducing emissions \\
\hline
\end{tabular}




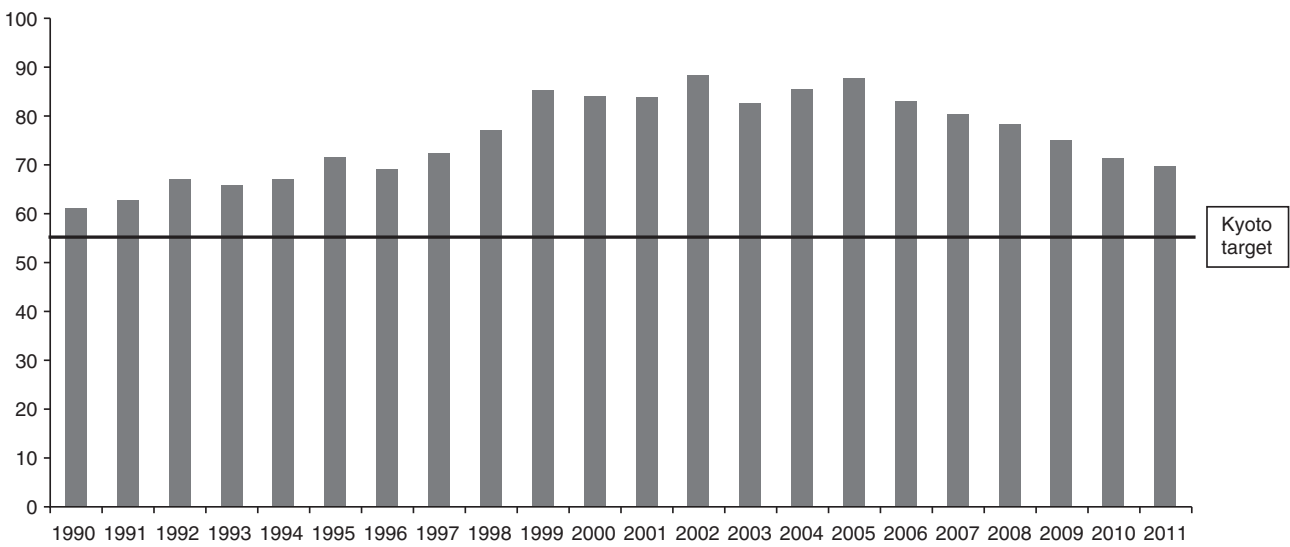

FIG URE 2 | Greenhouse Gas emissions (CO 2 equivalent) in Portugal (1990-2011), Tg (million tons). Source: Ref 71.

much like PNAC 2004. ${ }^{70}$ PNAC 2006 also set up the Executive Committee for the Climate Change Commission (CECAC in the Portuguese acronym), responsible for planning, monitoring and coordinating public policy, managing the Portuguese Carbon Fund, and acting as designated national authority for the market mechanisms of the Kyoto protocol.

Two years later, the government reviewed some of the PNAC 2006 targets pertaining to measures and policies on energy supply and to the increase in the uptake of biofuels in transport. Again these measures resulted mainly in the increase of renewable energy production but had little effect on other sectors, in particular road transport, which continued to grow.

Participation in the EU's ETS forced Portugal to adopt a National Plan for the Allocation of Emissions Allowances (PNALE) in 2005, which defined the total amount of emissions licences that could be allocated to industrial facilities. However, almost all sectors were given rather liberal quotas. Instead of providing an incentive to reduce emissions, PNALE awarded industry with sufficient margin for maneuvre to keep emissions at previous levels. In 2008, a second plan (PNALE II) was published, which represented a much stronger effort toward emissions reduction. Its policy design process was much more inclusive, encompassing industrial partners in the discussion.

The Portuguese Carbon Fund (FPC) was created in 2006 as a financial tool of the Portuguese government aimed at responding to the country's deviation from the Kyoto Protocol. It supports projects that result in emissions reduction, carbon sink projects and emission credits through the investment in the Kyoto Protocol's flexibility mechanisms and other instruments of the carbon market. Its impact is unknown as FPC is yet to be evaluated.

Four recent articles have analyzed Portugal's mitigation policies at different spatial levels.
From an international comparative perspective, Konidari and Mavrakis ${ }^{73}$ used the case of Portugal, alongside other seven European countries, to test their multicriteria analysis method for the quantitative evaluation of climate change mitigation policy instruments. Combining several criteria of environmental performance, political acceptability, and feasibility of implementation, they concluded that the EU's ETS is not effective for Portugal because environmental performance is zero and the other two criteria also achieved low grades. At the national level, Simões et al. ${ }^{59}$ estimated the contribution of Portuguese energy policies to the abatement of $\mathrm{CO}_{2}$ emissions costs for the year 2020. Drawing on six energy and environmental policy scenarios and assessing the impact of each policy measure, they concluded that the introduction of policies only increases marginal abatements costs.

In the third study, Pereira and Pereira ${ }^{74}$ sought to evaluate the economic cost of policies aimed at reducing carbon dioxide emissions from fossil fuel combustion by estimating their impact on economic activity. Their results point to a positive scenario, in which emissions reduction does not jeopardize economic activity and has even the potential to generate favorable economic outcomes, through fuel switching to natural gas and biomass, and a more intensive use of electricity in mobility. At a local level, Torres and Pinho ${ }^{72}$ used data on Portuguese local authorities to test the feasibility of a cap and trade system (Local Emissions Trading Scheme). Two sectors were considered-transport and land use, land-use change, and forestry-and results show that this system can be an important instrument to encourage low carbon policies.

As for forestry and agricultural land projects, some research has demonstrated that Common Agricultural Policy support to intensive agriculture 
in drought vulnerable regions in the south of Portugal has had negative effects, increasing vulnerability to water stress, which is expected to increase as a result of climate change. ${ }^{75}$

\section{Adaptation Policies}

The Portuguese government passed the National Strategy for Adaptation to Climate Change (ENAAC) in 2010, following a EU directive. ENAAC was structured around four objectives: improvement of information and knowledge (forecasts, indicators, and scenarios); reduction of vulnerabilities and enhancement of resilience (particularly to extreme phenomena); promotion of public participation and dissemination of information; development of international cooperation within the EU and the Portuguese Speaking African Countries. ${ }^{b}$ ENAAC outlined a series of actions to be undertaken in the areas of land-use planning, water, health, energy, biodiversity, and coastal zones. The first implementation period was to be 2010, under the coordination of CECAC; however, a government change in 2011 led to significant restructuring of the Ministry of Environment, a reduction in government agencies and the downgrading of environmental issues in general and climate change in particular in governmental priorities. ${ }^{c}$ At a time of severe economic and financial crisis, ENAAC was put on hold and by mid-2013 there was still little information on the work carried out by sectorial groups.

Several studies have pointed out weaknesses in adaptation governance in Portugal. Werners et al. ${ }^{78}$ have shown that strategic plans for river basins, in the case of the Guadiana river, do not specify options or adaptation opportunities nor take local activities into consideration. Huntjens et al.' ${ }^{79}$ analysis of policy learning and its structural constraints on water management showed that Portugal's management regime is characterized as single loop learning or $a d$ hoc problem solving. Low levels of policy learning are associated with less integrated cooperation structures (scarce participation of nongovernmental stakeholders and of different levels of government) and feeble information management, and result in less advanced adaptation strategies to deal with droughts. A civic culture for water management is lacking, which may raise tensions and generate conflicts in a context of greater scarcity, as a result of climate change. ${ }^{80}$

Schmidt et al. ${ }^{81}$ tackled the issue of coastal governance and the difficulties in adapting to climate change. A confusing planning framework and ineffective management of coastal areas, paired with financial difficulties, further endanger areas that are already under strong risk of erosion and flooding. These authors proposed progressive adaptive governance as a solution, by involving local communities, developing thorough scientific assessments of risk and finding alternative funding sources for coastal interventions. Rinaudo et al. ${ }^{82}$ drew on two case studies, one of which was carried out in the south of Portugal, to analyze stakeholder perceptions on the development of measures to adapt to climate change in underground water management, through scenario workshops with experts, institutional representatives, and farmers. They found that Portuguese participants favored mostly state intervention in the management of groundwater, rather than a self-regulatory scenario, but with farmers participating in the definition of the rules of use, monitoring and sanctions.

\section{Stakeholder Engagement}

Government initiatives that engage the civil society with regards to climate policies have been scarce. Despite requiring public consultation, PNAC 2004, PNAC 2006 and ENAAC, as well as more specific policy decisions, did not generate significant public discussion. The Climate Change Forum was created in 2008 with the aim of promoting interaction between CAC and the civil society but only met once a year until 2011 (no meetings were held since then) and has taken a top-down approach where those in charge simply inform stakeholders of what is being done, with no real space for active participation or feedback from civil society representatives. Environmental NGOs have been very critical of Portugal's climate change policies, ever since the start of the implementation of the Kyoto Protocol, which allowed the country to increase its emissions instead of promoting immediate investment in energy efficiency policies. ${ }^{4}$ The National Council for Environment and Sustainable Development has issued several statements pointing to insufficient governmental measures, the need to enhance civil society's engagement and to improve connections between mitigation and adaptation. ${ }^{83,84}$

\section{Meeting the Targets?}

Despite the economic slowdown since 2009, the closure of some industrial units and the increase of renewable energy production, after a decade of policymaking on climate change Portugal has not reached its Kyoto $\mathrm{CO} 2$ emissions targets (Figure 2) mainly due to a continuing excessive dependence on road transportation for both people and freight. Drought has also been an important factor as it has negatively 
impacted hydroelectric power. The contribution of hydroelectricity to the energy mix in Portugal is strongly variable due to the large climate variability. In 2003 it amounted to $33 \%$ of the total energy generation but decreased to $9.7 \%$ in 2005 due to an intense drought. ${ }^{85}$ This led to an increase in the weight of imported energy from $83.5 \%$ to $87.3 \% .{ }^{86}$

GHG emissions rose steadily between 1998 and 2005 at a higher rate than was foreseen by the Burden Sharing Agreements, reaching the highest figures in 2002 and 2005: 45\% above the reference year of 1990, an 18\% deviation from the 2008-2012 target. In 2006 emissions were still $39 \%$ above the target. Without effective mitigation policies, namely in terms of energy efficiency ${ }^{d}$ this situation was foreseeable. ${ }^{72}$ By failing to comply with targets, Portugal has been forced to buy emission licences from other countries, namely Latvia, in 2009. Only at the end of 2013 will it be known whether Portugal has met its targets, which appears likely due to the economic crisis and an increase in renewable energy production (through wind farms and domestic solar panels). This is noteworthy as in 2010 Portugal was in the 5th position after Latvia, Sweden, Austria and Finland with a value of $19.7 \%$ for the percentage share of renewable energies in gross final energy consumption in the EU$27 .{ }^{87}$ Since 2010 the investment in renewable energies has decreased significantly although the government goal of reducing the dependency on imported fossil fuels, mainly oil and gas, remains.

In summary, climate change policies in Portugal are marked by discontinuity. Progress has been mostly due to EU pressure and less so to the internal consistency of decisions. However, there are no studies assessing policy implementation that could shed light on whether being near to fulfilling the Kyoto targets is due to ecological modernization or to the effects of the economic crisis. Research is needed to understand how consistent change is and whether it is due to more sustainable practices. Likewise, studies are missing on stakeholder engagement and on the governance models (e.g. more regulatory or more liberal) that ought to be adopted either at the national or local scales.

\section{PUBLIC ENGAGEMENT WITH CLIMATE CHANGE}

Governmental policies are vital to address climate change and its impacts; however, without wider social engagement they are likely to be ineffective. Individuals, social groups and communities play a key role in developing appropriate responses to climate change and in steering public policy. In this section, we refer to various aspects of public understanding of and engagement with climate change in Portugal, namely concern, knowledge and views of responsibility, as well as behavior aimed at mitigating climate change. ${ }^{e}$ Besides academic research, we refer to survey data as it maps the distribution of opinions and views in ways that allow for cross-national and temporal comparisons. We also discuss people's perceptions and uses of different sources of information, trust in sources of information, and review research on media representations of climate change.

\section{High Levels of Concern and Low Levels of Knowledge}

Eurobarometer surveys, that cover all EU member states, have included questions on climate change since the 1980s. Portuguese respondents have consistently shown levels of concern above the European average: $42 \%$ stated that they were very concerned with 'global warming' in 1986, 63\% in 1995, and 47\% in 2002 (against European averages of 37, 54, and $39 \%$ respectively). ${ }^{88-90}$ Gallup conducted a large international survey of views on global warming in 1992. It showed that Portugal was amongst those countries where the issue was perceived as most serious (still, it ranked below loss of rain forest, water pollution, loss of ozone, and air pollution). ${ }^{91}$ In 2011, $75 \%$ considered climate change a very serious problem (above the EU average of $68 \%$ ). ${ }^{92}$ However, when asked in 2011 to mention the most serious problem that the world was facing, only $7 \%$ of Portuguese respondents chose climate change (against $20 \%$ of Europeans). The economic crisis was at the forefront of concerns in Portugal.

Other studies indicate that the Portuguese tend to display high levels of concern regarding the environment. In the First National Inquiry on Portuguese Representations and Practices, ${ }^{7}$ carried out in 1997, the environment emerged as one of the issues that people felt most concerned with at the national level and especially at the world level. ${ }^{8}$ In an open-ended study conducted in 2003, Delicado and Gonçalves ${ }^{93}$ found that people ranked 'environmental risks' second in their list of risk-related concerns. This study showed that people considered climate change a serious global issue but at the national level the highest degree of gravity was attributed to pollution and wildfires (which caused massive destruction in 2003). Various studies show that in Portugal levels of concern about the environment grow markedly when people are asked about the global rather than local scale. ${ }^{8,93,94}$ The global and/or foreign loci tend to be viewed more negatively than the spaces surrounding 
respondents. However, contrasting with findings elsewhere, ${ }^{95}$ a majority of the Portuguese participants in a 2007 survey study viewed climate change as a serious personal threat, ${ }^{96,97}$ with drought and health problems being perceived as the most serious impacts (in a previous survey in a region particularly prone to flooding up to $81 \%$ of respondents said that they had felt impacts of climate change ${ }^{98}$ ).

Back in 1992, the Gallup study showed that levels of knowledge on climate change were quite low in Portugal, which had one of the lowest rates of self-reported understanding of the issue. As in other countries, a high percentage of people volunteered CFCs and ozone as the main cause of global warming. There were also misperceptions of the role of nuclear power plants and aerosol sprays. The Portuguese also displayed low levels of knowledge about both local and global environmental issues in a study conducted in 1997 by Nave et al., ${ }^{10}$ and Schmidt et al. ${ }^{99}$ confirmed public confusion about the causes of climate change in 2003. More recently, Cabecinhas et al. (2008) detected a slight improvement in levels of knowledge despite the public's persistent difficulties in identifying certain sources of GHGs (such as agriculture and animal husbandry). As in many other countries, people in Portugal still tend to incorrectly associate climate change to the 'ozone hole'. ${ }^{96,97}$ A 2009 Eurobarometer survey ${ }^{100}$ also shows that the Portuguese feel poorly informed not only about the causes $(68 \%$ against $42 \%$ of EU average), but also about consequences (69\% against $42 \%$ ) and ways to combat climate change $(70 \%$ against $46 \%$ ). The relation between levels of knowledge and levels of concern among Portuguese citizens remains unaddressed in research. Why are people so concerned with climate change when they know so little about it? We return to research gaps in the final section of the article.

\section{Weak Behavioral Engagement}

Perceptions of responsibility to deal with climate change are an important aspect of public views. In Portugal, the state tends to be deemed as the main agent for the resolution of environmental problems. ${ }^{8}$ Paradoxically, while political powers are considered responsible for solving problems they are often seen as accomplices of economic power. ${ }^{5}$

Citizens' behavioral engagement with climate change appears to be quite limited. Cabecinhas et al. ${ }^{96}$ found that saving energy at home and recycling were the most frequent behaviors to mitigate climate change. Changing light bulbs was reported as a common behavioral intention. When asked what prevented them from doing more in relation to climate change, people mentioned the financial cost of some actions and lack of time. Lack of information was also a frequent perceived barrier. In a 2011 Eurobarometer survey (Figure 3), 56\% of the Portuguese respondents mentioned recycling (below the EU average of $66 \%$ ) and $29 \%$ mentioned reducing the consumption of disposable items but more significant actions obtained

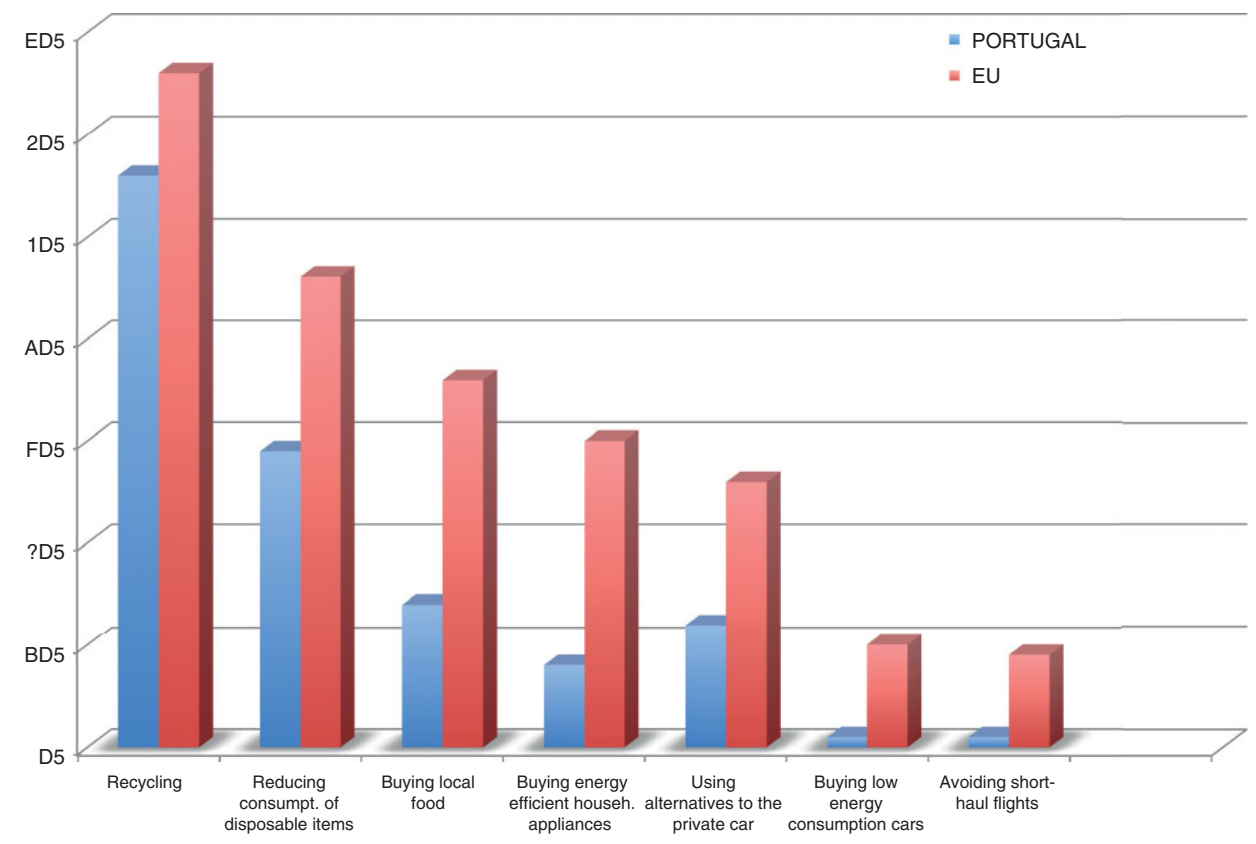

FIG URE 3 | Percentage of people declaring a given behavior to mitigate climate change in Portugal and the EU. Source: Ref 92, p. 28. 
much lower values, such as buying local food, buying energy efficient household appliances, using alternatives to the private car, buying low energy consumption cars, or avoiding short-haul flights. The contrast between expressed concern and behavior is striking and begs for expanded research. The fact that Portugal is an economy in transition that saw a rapid growth in the 1990s and early 2000s may have led to an increased consumerism and help explain some of the distribution of responses. Also, the fact that at the time of the survey Portugal was being severely hit by an economic and financial crisis may have brought down environmental issues in the scale of people's priorities. However, these are just general hypotheses that need to be tested and examined in conjunction with other factors.

Studies that use qualitative methods to study social representations of climate change are relatively rare. Cabecinhas et al. ${ }^{101,102}$ conducted several keyword association exercises to this purpose. In one study, carried out in 2005, participants were asked to write down the first few thoughts that came to mind about the 'most important problems' that humanity was faced with. 'Pollution' was one of the top ten ideas but climate change was not spontaneously evoked, which suggested that the issue had a low salience for participants. However, in a second study, when asked to freely associate words to climate change, participants brought up ideas of disease, death, and destruction, displaying a view of the issue as a severe threat. A study conducted in $2007^{102}$ found that climate change was mainly associated with droughts, flooding, and sea-level rising (there were also frequent associations to disease but proportionally fewer mentions of destruction and death than in 2005). Potential mitigation actions were only mentioned by $4 \%$ and $1 \%$ of participants in the 2005 and 2007 studies, respectively. These results suggest that people view themselves as victims of climate change but not as agents of resolution of the problem.

\section{Uses and Impacts of Information Sources: Complex Connections}

In Portugal television is the main source of information about climate change, followed by newspapers. ${ }^{96}$ People make a rather positive assessment of clarity, accuracy, and overall quality of information in their most frequently used medium. Analysis of the relation between patterns of use of information sources and level of knowledge on climate change showed a statistically significant result (frequent users of actively sought sources, such as the internet, had a higher level of knowledge than occasional users; users of public television channels had a higher level of knowledge than users of commercial channels). ${ }^{96}$ Uses of information sources did not seem to impact on perceptions of the probability of being affected by climate change or perceptions of risk. However, the pattern of use of information sources affected concern (frequent users of media sources displayed higher levels of concern than occasional users). Likewise, mitigation behavior and behavioral intentions were significantly affected by the use of actively sought sources and by the use of mass media (greater use associated to more frequent behavior), as well as by some demographic variables (age and gender). These results should not be interpreted as necessarily meaning a unilateral causal link. In other words, levels of concern, for instance, and forms of use of media sources could be mutually affecting each other.

Several studies have investigated people's trust in sources of information on environmental issues and, more specifically, on climate change. For many years, the Portuguese have tended to display low levels of trust in government and even less in unions and in business. ${ }^{5,103}$ In contrast, they have declared a high level of trust in environmental nongovernmental organizations (NGOs) and in scientists, followed by the media. However, levels of civic involvement with environmental NGOs were very low in the early 1990s and have continued that way. Citizens made nearly no use of democratic means of influence and organized intervention such as writing letters, demonstrating, petitioning, etc. Significantly they viewed the media as vehicles for performance of citizenship to the extent that they amplify popular protest and award it political weight and visibility. ${ }^{5}$ In 2000 , Nave et al. ${ }^{10}$ confirmed a high level of trust in the media, especially television, and low trust in corporations, political parties, and government (see also Ref 94). Scientists, health professionals, and environmental associations were viewed as the most trusted sources of information on climate change and the government, municipalities, and corporations were placed at the bottom of the scale in 2007. ${ }^{96,97}$ There is yet another paradox in the levels of trust in government and the media since, as we will see below, media discourses on climate change draw heavily on governmental voices.

\section{Media Reconstructions of Climate Change: Voices and Discourses}

Research on media coverage of climate change in Portugal was very scarce until the late 2000s. Dessai et al. ${ }^{104}$ mapped coverage in the Portuguese quality newspaper Público between 1991 and 2000 and found that peaks in volume coincided with international 
summits, such as the Rio Earth Conference in 1992 and the 1995 and 1997 Conferences of the Parties to the UNFCCC. Few articles focused on the national level. This tendency also emerged in Carvalho et al.'s ${ }^{105}$ analysis of three newspapers and a news magazine (Público, Correio da Manhã, Expresso, and Visão) between 1990 and 2007. In those media, politics (particularly intergovernmental politics) took centerstage. Governments were the most frequent social actors speaking for climate change $(46 \%-49 \%$ of all references to social actors in daily newspapers) followed by international organizations $(13 \%-17 \%)$. The local level was nearly absent and so was local government $(1 \%-3 \%)$. A key space in terms of GHG emissions and climate impacts, the local scale has been systematically backgrounded in the Portuguese media. Instead, the emphasis has been on global governance and expectations of appropriate responses to climate change have been tied, nearly exclusively, to international negotiations. Discourse analysis of media texts suggests that policy-makers have been hegemonic in the social construction of climate change with the media often reproducing official discourses (especially governments') and rarely analyzing policy alternatives or the impact of given political options. The newspaper Público is a relative exception to this tendency, providing more and deeper analysis. ${ }^{\mathrm{f}}$ In Portuguese media, scientific knowledge has been predominantly represented as consensual. Television has typically offered more dramatic representations of climate change then the press. ${ }^{105}$

A discourse of administrative rationality ${ }^{106}$ has had a very strong presence in the media; in other words, climate change has often been represented as solvable by state- and expert-led policies. Economic rationality, i.e., market solutions as the answer to climate change, has also figured prominently, together with ecological modernization. ${ }^{105}$ The latter, a variation of the sustainable development discourse, posits that action to mitigate climate change can generate economic dynamism and create new jobs and new riches. Sustainable development and ecological modernization have also been dominant in the discourses of a variety of social actors who speak on climate change. ${ }^{107}$ Carvalho and Pereira ${ }^{108}$ interviewed multiple types of social actors, from scientists to politicians and interest group representatives, regarding their communication practices on climate change and concluded that most social actors viewed the media as strategic to their interests and goals, although willingness, resources, and skills for developing media relations varied significantly.

Interviews and focus groups with journalists revealed that the status of climate change and the environment, in general, is very different in the newsrooms of quality and popular media. Perceived dependence of economic powers and limiting work conditions (time, resources, freedom to carry out investigative work) have shaped newsmaking practices and led to increased reliance on press releases and other communicative materials of different social actors (as opposed to independent research). Carvalho ${ }^{109}$ has argued that discursive constructions of climate change by powerful social actors have played a key influence in media discourses in Portugal. The factors discussed above are likely to contribute to this and help understand why a predominantly techno-managerial media discourse prevails in the country.

\section{SUMMARIZING AND LOOKING FORWARDS}

The three domains discussed above-climate science and assessment, policy development, and public engagement-reflect multiple aspects of the historical and social context of Portugal: the economic, political, and cultural challenges inherited from a long lasting repressive regime; the political transformations that ensued and the adhesion to the European Union; an endemic lack of governmental support to research (although much improved in the 1990s and early 2000s); the rapid economic and social transformations of the 1990s and the early 2000s; and the economic and financial crisis that started in the late 2000s, among others. In this final section, we offer a summary of the issues discussed in the article and then outline a research agenda that may contribute to understand under-researched questions, which in turn may help inform climate policies.

With the first integrated assessment of climate change impacts using climate scenarios from downscaled GCMs, conducted in 2002-2006, it became apparent that Portugal is particularly vulnerable to climate change and that the socioeconomic sectors and biophysical systems with higher vulnerability are water resources, agriculture, forests, biodiversity, coastal zones, health, and tourism. A strong research community has developed in the fields of climate science, vulnerabilities, impacts and adaptation, and mitigation to climate change after the turn of the century. Scientific research on mitigation strategies for Portugal has been used to construct the multiple versions of the National Programme for Climate Change. Public policies in planned adaptation to climate change have not yet benefited much from the climate change VIA research for Portugal. After the integrated multisectorial assessment of project SIAM ${ }^{1,29}$ research has 
been mostly sectorial and unrelated with the specific adaptation needs of the country.

Climate change policies in Portugal have been driven by external influences and pressure from the EU on several levels: adopting measures to fulfill commitments under the Kyoto protocol; gathering and monitoring emissions data; creating institutions for coordinating policies and legal instruments for regulating them. However, results have been somewhat disappointing. The initial targets were unambitious, allowing the country and its industries to raise levels of emissions. Consequently, key decisions were postponed (for instance, regarding clean energy generation and investment in transport and energy efficiency) and measures for improving performance were not implemented. Even after mitigation plans were approved (PNAC and PNALE), most measures were not put into practice. Climate change policies remained sectorial without a proper integration of climate change considerations into other policies. This situation is worsened by the hierarchical nature of climate change politics. Decisions have recurrently been made in a top-down manner. Policy plans and strategies have barely been publicized and discussed despite the fact that consultation and public participation are legally enshrined. Thus, the measures proposed in these plans and strategies lack a social basis of support and have never become endogenized.

Research on public understanding of and engagement with climate change in Portugal point to a number of apparent paradoxes and ambivalences. While expressed levels of concern are quite high, standing above many other countries, levels of knowledge and understanding of causes, impacts, and response options are quite low, clearly below the European average. Behavioral change to respond to climate change is also notably lower than the European average, with lack of money, lack of time, and lack of information being frequent perceived barriers. People rely heavily on mass media, and particularly television, as sources of information on climate change and display high levels of trust in their most used media. In contrast, trust in governments and business (who are key actors regarding climate change) is very low. Significantly, governments (both national and foreign) are the dominant social actors in media coverage of climate change, whereas local authorities, NGOs, and civil society occupy a very limited space. It is policy-makers discourse that is often reproduced in the media. Media(ted) discourses tend to promote technical and managerial solutions to climate change and to focus predominantly on the global (as opposed to national and local) scales. Those traits are unlikely to promote citizen engagement with climate change.

\section{Research Gaps and Policy Opportunities}

In each of the three areas covered by this article there are significant research gaps to be filled and opportunities to be explored, with potentially important policy implications. Firstly, it would be crucial to set up monitoring networks that would supply systematic information for climate change studies, since fundamental data is missing in various areas. Climate change impacts on Portugal's coastline are a key example. Assuring that geophysical observations (e.g., temperature, precipitation and sea level rise), as well as socioeconomic factors that may impact on them, are made available to stakeholders in a clear and meaningful manner should be an important goal.

It would be vital to carry out interdisciplinary and integrated research taking into account the physical, economic, social, and governance dimensions (as initiated by projects SIAM I and II and contravening the current trend for disperse and sectorial studies). This kind of approach would be key to assessing the impacts that the economic crisis has already had on mitigation and will have in the near future on adaptation, especially in areas where Portugal is especially vulnerable (water resources, extreme weather and climate events, vector-borne diseases, and sea level rise) and in relation to more fragile social groups (the elderly, socioeconomically deprived groups).

There is a significant lack of impact assessments, as well as mitigation and adaptation strategies, at the regional and local scales as only a few Portuguese towns have carried this out so far. At all scales, adaptation to extreme events resulting from climate change requires a particularly strong research focus.

Further research is clearly needed on the economic costs of climate change in Portugal in key socioeconomic sectors such as water resources, agriculture, forests, coastal zones, and tourism. The research effort on the potential physical effects and economic costs of major extreme weather and climate events and the major contingent social costs of such events is very modest. In part this may be due to the very deficient relation between scientific research and the implementation of public policies at the government and municipal levels in most socioeconomic sectors, including climate change.

Climate change politics and policies is the least researched of the three domains discussed in this article. Therefore, ample work is there to be done both in the analysis of climate policies and 
in the provision of advice to decision-makers. It would be useful to conduct a systematic assessment of climate change policies, in order to diagnose the factors that may hinder their implementation. Among others, it would be interesting to address the following questions: What is the role of institutional factors in climate policy design and implementation? To what extent does the country's political culture shape the success or failure of climate change policies?

Stakeholder involvement is critical to climate policies but has been undervalued in Portugal and this tendency has worsened in recent years. Whereas some research work with relevant stakeholders was being conducted at the time of writing, such as the project CHANGE for the adaptive governance of three critical coastal areas in Portugal ${ }^{57}$ and the adaptation project for the Lisbon water supplier, ${ }^{56}$ much more is needed.

EU leaders have endorsed the objective of reducing Europe's GHG emissions by $80 \%-95 \%$ by 2050 compared to 1990 levels. The possible pathways to reach this objective are still largely undefined for each EU country. Research in Portugal on how the country could contribute to reach this long-term goal should be promoted. Researchers could play an important role in the evaluation of alternatives to the policies advanced by official bodies in Portugal. In particular, it would be important to address questions such as the following: what are the economic and social drivers that lead Portugal to increase or decrease its GHG emissions (for instance, in the transport sector)?

Adaptation to climate change is an increasingly pressing concern in Portugal in view of its vulnerability especially regarding water resources, agriculture, forests, coastal zones, health and tourism. Hence, adaptation policies should occupy an important place in the country's research agenda. There is a clear need to address the costs of inaction particularly regarding extreme precipitation events and sea level rise.

The EU Strategy for Adaptation to Climate Change, might lead to a more fruitful collaboration between member States. However, it is likely that this will be limited by the increasing costs of climate change in the most vulnerable European countries, such as Portugal. Adaptation to climate change is very likely to become one of the most pressing issues for the Portuguese environmental policy in the coming decades. In view of the country's large socioeconomic differences, climate change will probably hit some social groups quite hardly. It is crucial to identify the most vulnerable social groups and to involve them in planning adaptation measures.
With regard to public engagement, a series of research opportunities exist that should be delved into. The role of knowledge as a prerequisite for behavioral engagement has been widely debated amongst scholars. While research has found no correlation between levels of knowledge and behavioral change to address climate change, and there is indication that behavioral engagement can occur in the absence of a complete understanding of the problem, studies in Portugal suggest that most people feel a significant lack of information and that this may be impacting the ways they relate to climate change. Hence, there may be space for well-targeted communication actions by public authorities and others. This should focus on the fundamentals of climate change but also, importantly, on climate policies and individual and communitylevel options. Communication and mobilization actions that are properly research-based would require a better understanding of differences between specific publics, as characterized by sociodemographic and cultural/value-related variables (e.g., views of nature, political preferences). Likewise, affective dimensions of people's relation to climate change, including emotional connections to places, landscapes or species that may be affected by climate change, should be considered but have hardly been paid heed in Portugal. Rather than based on old cognitive deficit notions, communication actions should be participatory and dialogic whenever possible.

The so-called value-action gap is of course well documented and apparently widespread around the world. Yet, it is particularly striking in Portugal, given the very high levels of concern and very low levels of behavior aimed at reducing GHG emissions. Examining the conditions under which people may actually modify their actions in that direction would be valuable. How can concern be productively activated into various forms of engagement with climate change? Under which social, political, and economic circumstances do people initiate changes in their practices, as well as in the modes of governance of their communities, which positively address climate change?

The public imaginary about climate change is influenced by various types of media content. In-depth analysis of modes of consumption of mediated content and the relation with understandings and attitudes is a challenging but important task for future research. In Portugal and elsewhere, new media, including social media, are a largely unexplored domain and likely to be of growing importance in, inter alia, influencing patterns of consumption of information, affective aspects, and behavioral and political engagement. Still, traditional media are likely to retain an important 
role in the social construction of climate change. Therefore, studies of journalistic work on climate change, including the role of values, source relations, and work routines, will continue to be called for.

We have argued above that the Portuguese public space has been dominated by a techno-managerial discourse that is likely to do little to inspire public engagement with climate change. It would be useful to analyze whether and how alternative discourses can be more empowering. Issues of agency and self-efficacy, and how they are related to different discourses and forms of communication, should be at the forefront of a future research agenda. Looking at those issues in the context of emerging social movements, like the Transition network, ${ }^{110}$ would also be a valuable addition to our understanding of people's relation to collective matters.

Finally, there are important connections between the three domains summarized above and the multiple disciplines that they involve, with significant potential for integrated research. Inter- and trans-disciplinary work is necessary to understand the interactions between natural and social processes and devise responses to the multiple challenges that Portugal faces regarding climate change.

Climate change policy development in Portugal should build more on research at all scales and domains. The use of scientific information to support decision-making is very likely to benefit policy formulation and evaluation. More and better ties between science and policy and stronger involvement of stakeholders are essential to improve mitigation and adaptation to climate change.

\section{NOTES}

a A journal of the Portuguese Physical Society that merged in 1998 with six other national journals of different European countries to form the European Physical Journal.

${ }^{b}$ Gomes ${ }^{76}$ shows that Portugal's support to Clean Development Mechanisms was very low until 2007 when agreements with African countries focusing on climate change and clean development were signed. The involvement of the Portuguese Institute of Development Aid (IPAD) in the ENAAC was also a positive development for cooperation on these issues. ${ }^{c}$ Sudden overturns in environmental policies are common in Portugal every time the government changes. ${ }^{69,70,77}$

${ }^{d}$ The National Plan for Energy Efficiency did not came into force until 2008.

${ }^{e}$ The term public engagement is used here as encompassing different ways of relating to or having a sense of connection with climate change.

$f$ No media engaged in assessing business performance in relation to GHG emissions. Corporations were thus left unchecked.

\section{REFERENCES}

1. Santos FD, Forbes K, Moita R. Climate Change in Portugal. Scenarios, Impacts and Adaptation Measures-SIAM Project. Lisbon: Gradiva; 2002. Available at: http://siam.fc.ul.pt/siamI_pdf/ (Accessed October 29, 2013).

2. UNFCCC. Portugal 2010 GHG Inventory Report (FCCC/ARR/2010/PRT). Available at: http://unfccc .int/national_reports/annex_i_ghg_inventories/national _inventories_submissions/items/5270.php. (Accessed October 29, 2013).

3. Lacasta NS, Barata PM. O Protocolo de Quioto sobre as alterações climáticas: Análise e perspectivas, Working Paper 1999, 1/98, 23 p.

4. Lacasta NS, Dessai S, Powroslo E. Consensus among many voices: articulating the European Union's position on climate change. Golden Gate Univ Law Rev 2002, 32:351-414.

5. Lima AV, Schmidt L. Questões ambientais-conhecimentos, preocupações e sensibilidades. Análise Social 1996, 31:205-227.
6. Schmidt L, Delicado A, Ferreira JG, Fonseca S, Seixas J, Sousa D, Truninger M, Valente S. O Ambiente em 25 Anos de Eurobarómetro. Lisbon: Observa; 2011, $72 \mathrm{p}$.

7. Almeida JF, ed. Os Portugueses e o Ambiente: I Inquérito Nacional às Representações e Práticas dos Portugueses sobre o Ambiente. Oeiras: Celta; 2000, $399 \mathrm{p}$.

8. Schmidt L, Valente S, Pinheiro J. País, percepção, retrato e desejo. In: Almeida JF, ed. Os Portugueses e o Ambiente: I Inquérito Nacional às Representações e Práticas dos Portugueses sobre o Ambiente. Celta: Oeiras; 2000, 33-101.

9. Lima AV, Coimbra E, Figueiredo A. Representações e valores sobre natureza e ambiente. In: Almeida JF, ed. Os Portugueses e o Ambiente: I Inquérito Nacional às Representações e Práticas dos Portugueses sobre o Ambiente. Celta: Oeiras; 2000, 7-31.

10. Nave JG, Horta A, Lorga C. Informação e cultura ambiental. In: Almeida JF, ed. Os Portugueses e o Ambiente: I Inquérito Nacional às Representações e 
Práticas dos Portugueses sobre o Ambiente. Celta: Oeiras; 2000, 103-144.

11. Garcia JL, Barata P, Matos G. Orientação, cidadania e responsabilização. In: Almeida JF, ed. Os Portugueses e o Ambiente: I Inquérito Nacional às Representações e Práticas dos Portugueses sobre o Ambiente. Celta: Oeiras; 2000, 145-184.

12. Peixoto JP, Oort AH. Physics of Climate. xxx: American Institute of Physics, New York; 1992, 520p.

13. Hansen J, Johnson D, Lacis A, Lebedeff S, Lee P, Rind D, Russell D. Climate impact of increasing atmospheric carbon dioxide. Science 1981, 213:957-966. doi: 10.1126/science.213.4511.957.

14. Hansen J, Fung I, Lacis A, Lebedeff S, Ruedy R, Russell $\mathrm{G}$, Stone P. Global climate changes as forecast by Goddard Institute for Space Studies three-dimensional model. J Geophys Res 1988, 93:9341-9364. doi: 10.1029/JD093iD08p09341.

15. National Academy of Sciences (NAS). Carbon dioxide and climate: a scientific assessment, Washington, D.C.; 1979.

16. National Academy of Sciences (NAS). Carbon dioxide and climate: a second assessment, Washington, D.C.; 1982.

17. Aguiar RJ, Santos FD. A three-component model for the assessment of the impact of high- $\mathrm{CO}_{2}$ levels and its application in Portugal. Portugaliae Physica 1987, 18:153-181.

18. Corte-Real J, Zhang X, Wang X. Downscaling GCM information to regional scales: a non-parametric multivariate approach. Clim Dyn 1995, 11:413-424. doi: 10.1007/BF00209515.

19. Corte-Real J, Qian B, Xu H. Regional climate change in Portugal: precipitation variability associated with large-scale atmospheric circulation. Int $J$ Climatol 1998, 18:619-635. doi: 10.1002/(SICI)10970088(199805)18:6<619::AID-JOC271>3.0.CO;2-T.

20. Trigo RM, Palutikof JP. Simulation of daily temperatures for climate change scenarios over Portugal: a neural network model approach. Climate Res 1999, 13:45-59. doi: 10.3354/cr013045.

21. Trigo RM, Palutikof JP. Precipitation scenarios over Iberia: a comparison between direct GCM output and different downscaling techniques. $J$ Climate 2001, 14:4422-4446. doi: 10.1175/15200442(2001)014<4422:PSOIAC > 2.0.CO;2.

22. Ramos AM, Trigo RM, Santo FE. Evolution of extreme temperatures over Portugal: recent changes and future scenarios. Climate Res 2011, 48:177-192. doi: $10.3354 / \mathrm{cr} 00934$.

23. Vicente-Serrano SM, Trigo RM, López-Moreno JI, Liberato MLR, Lorenzo-Lacruz J, Beguería S, MoránTejeda E, El Kenawy A. Extreme winter precipitation in the Iberian Peninsula in 2010: anomalies, driving mechanisms and future projections. Climate Res 2011, 46:51-65. doi: 10.3354/cr00977.
24. Costa A, Santos JA, Pinto JG. Climate change scenarios for precipitation extremes in Portugal. Theor Appl Climatol 2012, 108:217-234. doi: 10.1007/s00704011-0528-3.

25. Camuffo D, Bertolin C, Diodato N, Barriendos M, Dominguez-Castro F, Cocheo C, della Valle A, Garnier E, Alcoforado MJ. The western Mediterranean climate: how will it respond to global warming? Clim Change 2010, 100:137-142. doi: 10.1007/s10584010-9817-6.

26. Hoerling M, Eischeid J, Perlwitz J, Quan X, Zhang T, Pegion P. On the increased frequency of Mediterranean drought. J Climate 2012, 25:2146-2161. doi: 10.1175 /JCLI-D-11-00296.1.

27. Costa AC, Soares A. Trends in extreme precipitation indices derived from a daily rainfall database for the south of Portugal International. J Climatol 2009, 29:1956-1975. doi: 10.1002/joc.1834.

28. Giorgi F. Climate change hot-spots. Geophys Res Lett 2006, 33:L08707. doi: 10.1029/2006GL025734.

29. Santos FD, Miranda P. Alterações Climáticas em Portugal. Cenários, Impactos e Medidas de Adaptação, Projecto SIAM II. Lisbon : Gradiva, 2006. Available at: http://www.siam.fc.ul.pt/. (Accessed October 29, 2013).

30. Da Cunha LV, De Oliveira RP, Nascimento J, Ribeiro L. Impacts of climate change on water resources: a case-study for Portugal. In: Water in Celtic Countries: Quantity, Quality and Climate Variability. Proceedings of the Fourth InterCeltic Colloquium on Hydrology and Management of Water Resources, Guimarães, Wallingford, Portugal, July 2005, vol. 310. xxx: IAHS Publ; 2007, 37-48.

31. Freitas MC, Andrade C, Cachado C, Cardoso AC, Monteiro JH, Brito P, Rebelo L. Coastal landloss associated with sea-level rise assessed by aerial videotape-assisted vulnerability analysis: the case of mainland Portugal. J Coast Res 2006, 39:1310-1315.

32. Calheiros JM, Casimiro E, Santos FD. Human health impacts of climate change in Portugal: temperaturerelated deaths in Lisbon. Epidemiology 2002, 13:562. doi: 10.1289/ehp.8431.

33. Casimiro E, Calheiros JM, Santos FD, Kovats S. National assessment of human health effects of climate change in Portugal: approach and key findings. Environ Health Perspect 2006, 114:1950-1956. doi: 10.1289/ehp.8431.

34. Lemos RL, Sansó B. Spatio-temporal variability of ocean temperature in the Portugal Current System. J Geophys Res 2006, 111:C04010. doi: 10.1029/2005JC003051.

35. Nunes JP, Seixas J, Keizer JJ, Ferreira AJD. Sensitivity of runoff and soil erosion to climate change in two Mediterranean watersheds. Part I: model parameterization and evaluation. Hydrol Process 2009, 23:1202-1211. doi: 10.1002/hyp.7247. 
36. Nunes JP, Seixas J, Pacheco NR. Vulnerability of water resources, vegetation productivity and soil erosion to climate change in Mediterranean watersheds. Hydrol Process 2007, 22:3115-3134. doi: 10.1002/hyp.6897.

37. Coelho C, Silva R, Veloso-Gomes F, Taveira-Pinto F. Potential effects of climate change on northwest Portuguese coastal zones. ICES J Mar Sci 2009, 66:1497-1507. doi: 10.1093/icesjms/fsp132.

38. Lopes CL, Silva PA, Dias JM, Rocha A, Picado A, Plecha S, Fortunato AB. Local sea level change scenarios for the end of the 21st century and potential physical impacts in the lower Ria de Aveiro (Portugal). Cont Shelf Res 2011, 31:1515-1526. doi: 10.1016/j.csr.2011.06.015.

39. Trigo RM, Ramos AM, Nogueira PJ, Santos FD, Garcia-Herera R, Santo FE. Evaluating the impact of extreme temperature based indices in the 2003 heatwave excessive mortality in Portugal. Environ Sci Policy 2009, 12:844-854. doi: 10.1016/j.envsci.2009.07.007.

40. Carvalho A, Monteiro A, Solman S, Miranda AI, Borrego C. Climate-driven changes in air quality over Europe by the end of the 21st century, with special reference to Portugal. Environ Sci Policy 2010, 13:445-458. doi: 10.1016/j.envsci.2010.05.001.

41. Garrett P, Casimiro E, Pulquério M, Santos FD. Statistical approach to estimate the impact of climate change on daily ozone concentrations. Int J Glob Warm 2012, 4:273-286. doi: 10.1504/IJGW.2012.049446.

42. Andrade C, Pires HO, Taborda R, Freitas MC. Projecting future changes in wave climate and coastal response in Portugal by the end of the 21st century. $J$ Coast Res 2007, 50:253-257.

43. Santos FD, Aguiar R. CLIMAAT II, Clima e Meteorologia dos Arquipélagos Atlânticos, Impactos e medidas de adaptação às alterações climáticas no Arquipélago da Madeira. Funchal: Direcção Regional do Ambiente da Madeira, 2006, Available at: http:// www.sra.pt/files/PDF/Destaques/Brochura\%20CLIM AAT_II_MadeiraFINAL.pdf. (Accessed October 29, 2013).

44. Cruz MJ, Aguiar R, Correia A, Tavares T, Pereira JS, Santos FD. Impacts of climate change on the terrestrial ecosystems of Madeira. Int J Des Nat Ecodyn 2009, 4:413-422. doi: 10.2495/DNE-V4-N4-413-422.

45. SIAM-Sintra, Strategic plan for adaptation and mitigation of climate change in the Sintra municipality, Câmara Municipal de Sintra, 2009. Available at: http://www.siam.fc.ul.pt/siam-sintra/. (Accessed October 29, 2013).

46. Aguiar RJ, Santos FD. Energy and GHG Emissions: An Exercise of Prospective for Portugal up to 2070, Project MISP, Climate Change: Mitigation Strategies for Portugal. Lisbon: Calouste Gulbenkian Foundation; 2007, 48 p.
47. SIAM-Cascais, Strategic Plan for Adaptation and Mitigation of Climate Change in the Cascais Municipality, Câmara Municipal da Cascais, 2010, Available at: http://www.siam.fc.ul.pt/PECAC/. (Accessed October 29, 2013).

48. IB, Iberia change-forecasting impacts of climate change on Iberian biodiversity, 2012. Available at: http://www.ibiochange.mncn.csic.es/iberiachange/. (Accessed October 29, 2013).

49. Araújo MB, Thuiller W, Pearson RG. Climate warming and the decline of amphibians and reptiles in Europe. J Biogeogr 2006, 33:1712-1728. doi: 10.1111/j.1365-2699.2006.01482.x.

50. Araújo MB, Rozenfeld R, Rahbek C, Marquet PA. Using species co-occurrence networks to assess the impacts of climate change. Ecography 2011, 34:897-908. doi: 10.1111/j.16000587.2011.06919.x.

51. Carvalho A, Flannigan MD, Logan KA, Miranda AI, Borrego C. The impact of spatial resolution on area burned and fire occurrence projections in Portugal under climate change. Clim Change 2010, 98:177-197. doi: 10.1007/s10584-009-9667-2.

52. Vinagre C, Santos FD, Cabral H, Costa MJ. Impact of climate warming upon fish assemblages of the Portuguese coast under different scenarios. Reg Environ Change 2011, 11:779-789. doi: 10.1007/s10113-011-0215-z.

53. CLITOP, Climate change and tourism in Portugal, potential impacts and adaptation measures, 2007. Available at: http://www.siam.fc.ul.pt/clitop/. (Accessed October 29, 2013).

54. Alcoforado MJ, Andrade H. Nocturnal urban heat island in Lisbon (Portugal): main features and modelling attempts. Theor Appl Climatol 2006, 84(1-3):151-159. doi: 10.1007/s00704-005-0152-1.

55. Alcoforado MJ, Andrade H, Lopes A, Vasconcelos J. Application of climatic guidelines to urban planning: the example of Lisbon (Portugal). Landsc Urban Plan 2009, 90:56-65. doi: 10.1016/j.landurbplan. 2008.10.006.

56. ADAPTACLIMA, Adaptar o Ciclo Urbano da Água a Cenários de Alterações Climáticas. Available at: http://siam.fc.ul.pt/adaptaclima-epal/. (Accessed October 29, 2013).

57. CHANGE, Mudanças Climáticas, Costeiras e Sociais. Available at: http://www.projectochange.ics.ul.pt/. (Accessed October 29, 2013).

58. CIRAC, Cartas de Inundação e Risco em Cenários de Alterações Climáticas. Available at: http://siam.fc.ul.pt/cirac/. (Accessed October 29, 2013).

59. Simões S, Cleto J, Fortes P, Seixas J, Huppes G. Cost of energy and environmental policy in Portuguese $\mathrm{CO} 2$ abatement-scenario analysis to 
2020. Energy Policy 2008, 36:3598-3611. doi: 10.1016/j.enpol.2008.06.004.

60. Dessai S, Michaelowa A. Burden sharing and cohesion countries in European climate policy: the Portuguese example. Clim Policy 2001, 1:327-341.

61. Comissão para as Alterações Climáticas. Programa Nacional para as Alterações Climáticas 2001. CAC, Lisboa, 2002.

62. Resolução de Conselho de Ministros (RCM), n. 119/2004, DR. N. 179, July 31, 2004.

63. Resolução de Conselho de Ministros (RCM) n. 104/2006, DR. N. 162, August 26, 2006.

64. Resolução de Conselho de Ministros (RCM) n. 93/2010, DR. N. 230, November 26, 2010.

65. Resolução de Conselho de Ministros (RCM) n. 53/2005, DR. N. 44, March 3, 2005.

66. Resolução de Conselho de Ministros (RCM) n. 1/2008, DR. N. 3, January 3, 2008.

67. Resolução de Conselho de Ministros (RCM) n. 24/2010, DR. N. 64, April 1, 2010.

68. Agência Portuguesa do Ambiente. Roteiro Nacional de Baixo Carbono 2050. Lisboa: APA; 2012.

69. Schmidt L. Políticas ambientais: escalas e desajustes. In: Villaverde-Cabral M, Wall K, Aboim S, Silva FC, eds. Itinerários. Lisbon: Imprensa de Ciências Sociais; 2008.

70. Schmidt L. Políticas ambientais—um balanço. Letras Com-vida 2010, 2:86-92.

71. European Environmental Agency Annual European Union greenhouse gas inventory 1990-2011, 2013. Available at: http://www.eea.europa.eu/data -and-maps/data/data-viewers/greenhouse-gases-viewer. (Accessed October 29, 2013).

72. Torres M, Pinho P. Encouraging low carbon policies through a Local Emissions Trading Scheme (LETS). Cities 2011, 28:576-582. doi: 10.1016/j.cities.2011.06.005.

73. Konidari P, Mavrakis D. A multi-criteria evaluation method for climate change mitigation policy instruments. Energy Policy 2007, 35:6235-6257. doi: 10.1016/j.enpol.2007.07.007.

74. Pereira AM. Pereira RMM Is fuel-switching a noregrets environmental policy? VAR evidence on carbon dioxide emissions, energy consumption and economic performance in Portugal. Energy Econ 2010, 32:227-242. doi: 10.1016/j.eneco.2009.08.002.

75. Costa MAM, Moors EJ, Fraser EDG. Socioeconomics, policy, or climate change: what is driving vulnerability in southern Portugal? Ecol Soc 2011, 16:28.

76. Gomes C. Alterações climáticas e desenvolvimento limpo. Lisbon: Esfera do Caos; 2010, 168 p.

77. Soromenho-Marques V. O futuro frágil - Os desafios da crise global de ambiente. Lisbon: Publicações Europa-América; 1998, 225 p.
78. Werners S, Tabara J, Neufeldt H, Dai X, Flachner Z, West J, Cots F, Trombi G, McEvoy D, Matczak $\mathrm{P}$, et al. Mainstreaming adaptation in regional land use and water management. In: Hulme M, Neufeldt $\mathrm{H}$, eds. Making Climate Change Work for Us: European Perspectives on Adaptation and Mitigation Strategies. Cambridge: Cambridge University Press; 2010, 230-260.

79. Huntjens P, Pahl-Wostl C, Rihoux B, Schlüter M, Flachner Z, Neto S, Koskova R, Dickens C, Kiti IN. Adaptive water management and policy learning in a changing climate: a formal comparative analysis of eight water management regimes in Europe, Africa and Asia. Water Manage 2011, 163:145-163. doi: 10.1002/eet.571.

80. Schmidt L, Prista P. Portugal—changement climatique, eau et société. Grande Europe (Dossier Face aux Désordres Climatiques) 2010, 19:49-57.

81. Schmidt L, Prista P, Saraiva T, O’Riordan T, Gomes C. Adapting governance for coastal change in Portugal. Land Use Policy 2012, 31:314-325. doi: 10.1016/j.landusepol.2012.07.012.

82. Rinaudo JD, Montginoul M, Varanda MP, Bento S. Envisioning innovative groundwater regulation policies through scenario workshops in France and Portugal. Irrigation Drainage 2012, 61(S1):65-74. doi: 10.1002/ird.1661.

83. CNADS (Conselho Nacional do Ambiente e do Desenvolvimento Sustentável) Parecer sobre o Programa Nacional para as Alterações Climáticas. Versão 2001, 2002. Available at: http://www.cnads.pt/index. php?option $=$ com_docman\&task=doc_download\&gi $\mathrm{d}=109$ \&Itemid=84. (Accessed October 29, 2013).

84. CNADS (Conselho Nacional do Ambiente e do Desenvolvimento Sustentável) Parecer do Conselho Nacional do Ambiente e do Desenvolvimento Sustentável sobre a Proposta de Estratégia Nacional de Adaptação às Alterações Climáticas 2009. Available at: http://www.cnads.pt/index.php?option =com_docman \&task=doc_download\&gid $=119 \&$ Itemid $=84$.

(Accessed October 29, 2013).

85. DGEG, Direcção Geral de Energia e Geologia, Renováveis Estatísticas Rápidas-Janeiro 2008. Available at: http://www.dgeg.pt/. (Accessed October 29, 2013).

86. APREN, Associação de Energias Renováveis As renováveis em Portugal. Abril de 2013. Available at: http://www.apren.pt/fotos/editor2/as_renovaveis_em_ portugal_apren_abr2013.pdf. (Accessed October 29, 2013).

87. Eurostat Share of renewables in gross inland energy consumption 2010. Available at: http://epp.eurostat. ec.europa.eu/statistics_explained/images/e/e8/Share_of _renewables_in_gross_inland_energy_consumption $\%$ 2C_2010_\%28\%25\%29.png. (Accessed October 29, 2013). 
88. European Commission. The Europeans and Their Environment in 1986 (Special Eurobarometer 30). Brussels: European Commission; 1986, 135 p.

89. European Commission. Europeans and the Environment(Special Eurobarometer 88). Brussels: European Commission; 1995, 96 p.

90. European Commission. Attitudes Towards Environment (Special Eurobarometer 180). Brussels: European Commission; 2002, 43 p.

91. Brechin SR. Comparative public opinion and knowledge on global climatic change and the Kyoto Protocol: the U.S. versus the world? Int I Sociol Soc Policy 2003, 23:106-34. doi: 10.1108/01443330 310790318

92. European Commission. Climate Change (Special Eurobarometer 372). Brussels: European Commission; 2011, 84 p.

93. Delicado A, Gonçalves ME. Os portugueses e os novos riscos: resultados de um inquérito. Análise Social 2007, 42:687-718.

94. Rodrigues F, Figueiredo M, Lima L Percepção de risco das alterações climáticas globais em ilhas: a percepção dos terceirenses no arquipélago dos Açores- Portugal. In I Congresso de Desenvolvimento Regional de Cabo Verde, 2010, 3416-3427. Available at: http://www.apdr.pt/congresso/2009/pdf/Sessã o35/35A.pdf. (Accessed October 29, 2013).

95. Lorenzoni I, Nicholson-Cole S, Whitmarsh L. Barriers perceived to engaging with climate change among the UK public and their policy implications. Glob Environ Chang 2007, 17:445-59. doi: 10.1016/j.gloenvcha.2007.01.004.

96. Cabecinhas R, Lázaro A, Carvalho A. Media uses and social representations of climate change. Carvalho, A. Communicating Climate Change: Discourses, Mediations and Perceptions. Braga: Centro de Estudos de Comunicação e Sociedade, Universidade do Minho; 2008: 170-189. Available at: http://www.lasics.uminho.pt/ojs/index.php/climate change. (Accessed October 29, 2013).

97. Lázaro A, Cabecinhas R, Carvalho A. Uso dos media e envolvimento com as alterações climáticas. In: Carvalho A, ed. As Alterações Climáticas, os Media e os Cidadãos. Grácio Editor: Coimbra; 2011, 195-222.

98. Coelho CA, Valente SM, Pinho LD, Carvalho TM, Ferreira AD, Figueiredo EM A percepção social das alterações climáticas e do risco de cheia. In Associação
Portuguesa de Recursos Hídricos, ed. $7^{\circ}$ Congresso da Água, 2004. Available at: http://www.aprh. pt/congressoagua2004/PDF/64.pdf. (Accessed October 29, 2013).

99. Schmidt L, Nave JG, Pato J. As alterações climáticas no quotidiano: Estudo comportamental de curta duração. Lisbon: Observa; 2003, 75 p.

100. European Commission. Europeans' Attitudes Towards Climate Change(Special Eurobarometer 322). Brussels: European Commission; 2009, 134 p.

101. Cabecinhas R, Lázaro A, Carvalho A. Lay representations on climate change. In: Proceedings of IAMCR's 25th Conference. Cairo: IAMCR; 2006, 504-508.

102. Cabecinhas R, Lázaro A, Carvalho A. Representações sociais sobre alterações climáticas. In: Carvalho A, ed. As Alterações Climáticas, os Media e os Cidadãos. Grácio Editor: Coimbra; 2011, 177-194.

103. Schmidt L, Trüninger M, Valente S. Problemas ambientais, prioridades e quadro de vida. In: Almeida JF, ed. Os Portugueses e o Ambiente: II Inquérito Nacional às Representações e Práticas dos Portugueses sobre o Ambiente. Celta: Oeiras; 2004, 65-172.

104. Dessai S, Branco K, Doria M. Climate change and media in Portugal: preliminary results. Poster presented at the conference on 'Climate Change Science, Economics and Politics’, Lisbon, 2001.

105. Carvalho A, Pereira E, Rodrigues AT, Silveira AP. A reconstrução mediática das alterações climáticas. In: Carvalho A, ed. As Alterações Climáticas, os Media e os Cidadãos. Coimbra: Grácio Editor; 2011, 105-144.

106. Dryzek J. The Politics of the Earth Environmental discourses. Oxford: Oxford University Press; 1997, $220 \mathrm{p}$.

107. Carvalho A. Discursos de actores sociais sobre alterações climáticas. In: Carvalho A, ed. As Alterações Climáticas, os Media e os Cidadãos. Grácio Editor: Coimbra; 2011, 43-65.

108. Carvalho A, Pereira E. Estratégias comunicativas dos actores sociais. In: Carvalho A, ed. As Alterações Climáticas, os Media e os Cidadãos. Grácio Editor: Coimbra; 2011, 67-102.

109. Carvalho A. Conclusões. In: Carvalho A, ed. As Alterações Climáticas, os Media e os Cidadãos. Grácio Editor: Coimbra; 2011, 223-240.

110. Transition Network. Available at: http://www.transitionnetwork.org/. (Accessed October 29, 2013). 